\title{
mRNA LEVELS OF PEROXISOME PROLIFERATOR-ACTIVATED RECEPTORS AND THEIR COACTIVATORS ARE AFFECTED BY GLUCOSE DEPRIVATION AND OLEATE IN HUMAN HEPATOMA HepG2 CELLS
}

\author{
Katerina Bogdanova ${ }^{\mathrm{a}, \mathrm{c} *}$, Lenka Uherkova ${ }^{\mathrm{b}, \mathrm{c}}$, Hana Poczatkova ${ }^{\mathrm{a}}$, Miroslav Rypka ${ }^{\mathrm{a}}$, \\ Jaroslav Vesely ${ }^{\mathrm{a}}$
}

\author{
a Department of Pathological Physiology, Faculty of Medicine and Dentistry, Palacky University, Hnevotinska 3, 775 15 \\ Olomouc, Czech Republic \\ b L. U., National Reference Laboratory for Lyme Disease, National Institute of Public Health, Srobarova 48, \\ 10042 Prague 10, Czech Republic \\ c These two authors have contributed equally to this study \\ e-mail: kapalinakb@centrum.cz
}

Received: October 13, 2007; Accepted: November 2, 2007

Key words: Starvation/Glucose/Oleic acid/Peroxisome proliferator-activated receptor (PPAR)/PPAR- $\gamma$ coactivator (PGC)/ mRNA stability/Superinduction/HepG2 cells

Aims: Very modest changes in mRNA stability can affect critical points in cellular energy pathways. The aim of this study was to investigate the impact of energy abundant substrates on peroxisome proliferator-activated receptors (PPARs) and PPAR- $\gamma$ coactivators (PGCs) mRNA's steady-state levels.

Methods: Quantitative RT-PCR study was performed to assess the effect of zero or normal ( $5 \mathrm{mmol} / \mathrm{l}) \mathrm{glucose}$ and/or oleic acid (0.3 mmol/1) on mRNA levels of (PPARs) (PGCs) in HepG2 cells.

Results: PGC-1 $\alpha$ mRNA was significantly upregulated in glucose deprived cells ( $123 \%$ of the control level; $p<0.05$ ), while PGC-1 $\beta$ mRNA was significantly enhanced in oleate-fed cells ( $134 \%$ and $160 \%$ of control levels for zero glucose plus oleate and normal glucose plus oleate, respectively; $\mathrm{p}<0.05)$ during the $0.5 \mathrm{~h}$ incubation. Upon the $4 \mathrm{~h}$ incubation, PPAR- $\gamma 1$ and PGC- $1 \alpha$ mRNAs were significantly elevated in cells lacking glucose $(142 \%$ and $163 \%$ of control levels, respectively; $\mathrm{p}<0.05)$. Oleate significantly suppressed PPAR- $\alpha$ and PGC- $1 \beta$ mRNA levels in glucose-deprived cells ( $58 \%$ and $49 \%$ of control levels, respectively; $\mathrm{p}<0.05$ ). PPAR $-\gamma 1$ and $-\gamma 2$ mRNAs were significantly superinduced when the cells were treated with cycloheximide, whereas PPAR- $\alpha$ and PGC- $1 \alpha$ and-1 $\beta$ mRNAs were destabilized. Upon actinomycin D treatment, glucose shortage significantly stabilized PPAR- $\alpha$ mRNA, while PGC- $1 \alpha$ mRNA was destabilized by oleate in glucose-deprived cells.

Conclusions: Our findings provide evidence that transcriptional processes that are under the control of energetic substrates are interconnected with concurrent translational processes that can change stability of mRNAs.

\section{INTRODUCTION}

Living organisms must continuously adapt their energy metabolism to a discontinuous supply of nutrients. In mammals, the relationship of carbohydrate metabolism to fat utilization is complex. The liver plays a key role in the maintenance of systemic energetic homeostasis. During a medium- to long-term fast, gluconeogenesis is turned on to maintain appropriate blood glucose levels. In addition, adipose tissue acts with the liver to ensure glucose homeostasis during the postabsorptive period. Fatty acid oxidation is activated, providing energy for tissues and, in the liver, for the gluconeogenic process. Collaterally, ketone bodies are exported from the liver providing an alternative fuel source to glucose. According to the conventional view, systemic transition from the fed to fasted state is entirely orchestrated by hormones. Upon starvation, when the insulin:glucagon ratio is low, gluconeogenesis and lipolysis are induced by a synergistic action of glucagon and glucocorticoids, while lipogenesis is inhibited. The hormones mainly elicit these changes by modulating transcription of genes that are involved in glucose and fatty acid metabolism ${ }^{1}$.

Over the recent years, it has become apparent that the control of transcription by nutrients and their cellular metabolites provides another mechanism, additional to hormones, that allows cells to respond to changes in their nutritional environment. More specifically, amino acids, glucose, and non-esterified, or free fatty acids (FFA) have been all recognized as universal cellular regulators ${ }^{1}$. For instance, available data suggest that mechanisms of FFA-induced changes involve a number of DNA-binding transcription factors executing pleiotropic metabolic actions. Of these, peroxisome proliferator-activated receptors (PPAR)- $\alpha,-\beta$, and $-\gamma$ have emerged as a molecular rationale for the link between fatty acid and/or glucose availability and the gene expression control. ${ }^{2}$ The primary PPAR subtype in the liver is PPAR- $\alpha$. PPAR- $\alpha$ controls many aspects of energy metabolism, particularly those involved in liver glucose synthesis, lipid oxidation and glucose sparing processes that are activated in the postabsorptive state. PPAR- $\alpha$-null mice suffer from marked hy- 
poglycaemia upon fasting and are steatotic owing to a decreased FFA oxidation capacity. Pharmacological agonists of PPAR- $\alpha$ are known as antihyperlipidemic agents improving the impaired insulin sensitivity ${ }^{3,4,5}$.

Moreover, recent studies have revealed the presence of accessory, ligand-independent transcriptional coactivator molecules in cells that are essential for the activation of nuclear receptors and transcription factors. In particular, a family of coactivators closely related to PPARs and involving two PPAR- $\gamma$-coactivators (PGC- $1 \alpha$ and $-1 \beta$ ) together with PGC-1-related coactivator (PRC) have been discovered and shown to play prominent roles in both physiological and pathological processes ${ }^{6,7}$. Under fed conditions, PGC- $1 \alpha$ is suppressed by insulin and its abundance in liver is low. However, it has been found to dramatically increase in fasted animals ${ }^{8,9}$. PGC- $1 \alpha$-null mice exhibit impaired gluconeogenesis, fasting hypoglycaemia, and liver steatosis upon fasting ${ }^{10-12}$, whereas PGC$1 \alpha$ overexpression in the liver is associated with elevated hepatic glucose production ${ }^{9}$. These data are of clinical importance since impaired expression of PPARs and/or PGCs probably contributes to hyperglycaemia in diabetes mellitus and/or liver steatosis in obesity.

Elucidation of the complex interplay between hormones, substrates, transcriptional factors, and genes is critical for our understanding of both beneficial and harmful effects of nutrition on human health. Energy abundant substrates, such as carbohydrates and fats, have been widely acknowledged to have different effects, to selectively influence the responses of specific hepatic genes, depending upon the particular nutritional and hormonal context ${ }^{1}$. Despite much recent progress, the function of PPAR/PGC machinery in several basic aspects of the hepatic fasting response remains unexplored. Little is known about direct action of the energetic nutrients on the expression of genes in hepatocytes upon starvation. In particular, the control of steady-state levels of mRNA, representing the outcome of mutually competing processes of mRNA synthesis and degradation, is now increasingly appreciated as a powerful mechanism for regulating gene activity in virtually all cells in the human body ${ }^{13}$. In this regard, very modest changes in mRNA stability and decay have been described to impact critical points in cellular pathways important for energy metabolism that have been correlated with serious metabolic disturbances in human beings ${ }^{6,14-16}$.

This quantitative RT-PCR study was conducted to investigate, in the absence of hormones, the effects of glucose and oleic acid on the cytoplasmic mRNA content of several molecules functionally clustered round PPAR transcription factors in human hepatoma-derived HepG2 cells. First, we focused on PPAR- $\alpha,-\gamma 1$, and $-\gamma 2$ mRNA levels. Second, assuming that expression of the PPAR coactivators may also be affected, we included PGC- $1 \alpha$ and $-1 \beta$ mRNAs in our study. Third, we analyzed changes in mRNA levels of the studied molecules using transcriptional and translational inhibitors to get insight into the mechanisms behind them.

\section{MATERIALS AND METHODS}

\section{Materials}

Eagle's minimum essential medium (EMEM), penicillin, streptomycin, sodium pyruvate, L-glutamin, trypsin, bovine serum albumin (BSA), fatty acid-free BSA, D-glucose, cycloheximid, actinomycin-D, and oleic acid were purchased from Sigma-Aldrich (St. Louis, MO). Glucosefree Dulbecco's modified Eagle's medium (DMEM) and fetal bovine serum (FBS) was obtained from Gibco (Grand Island, NY).

\section{Preparation of the oleic acid-BSA complex}

Fatty acid-free BSA was dissolved in EMEM medium supplemented with $1 \%$ FBS and oleic acid was added to this solution to achieve 2:1 oleic acid-BSA ratios. The mixture was vortexed and sonicated until optically clear and used immediately.

\section{Cell culture}

HepG2 cells (ATCC, Rockville, MD, USA) were grown to about $80 \%$ confluence in Eagle's minimum essential medium (EMEM) supplemented with $10 \%$ fetal bovine serum (FBS), $1 \mathrm{mmol} / 1$ sodium pyruvate, $2 \mathrm{mmol} / 1$ L-glutamine, and $50 \mathrm{IU} / \mathrm{ml}$ penicillin/streptomycin in a humidified $5 \% \mathrm{CO}_{2} / 95 \%$ air atmosphere at $37{ }^{\circ} \mathrm{C}$. During this period the medium was replaced by fresh medium (containing all supplements) every $48 \mathrm{~h}$. The medium was then switched to Dulbecco's modified Eagle's medium (DMEM) lacking glucose supplemented with 1\% FBS (w/ v). BSA was adjusted in all target samples and controls to a final concentration of $1 \%(\mathrm{w} / \mathrm{v})$. Based on our preliminary results the experimental treatment was carried out for 0.5 or $4 \mathrm{~h}$ periods with D-glucose at $0 \mathrm{mmol} / 1$ or $5 \mathrm{mmol} / \mathrm{l}$ concentrations without or with the above oleic acid-BSA complex added to a final concentration of $0.3 \mathrm{mmol} / 1$ oleic acid. Three independent experiments were performed for each time interval and glucose and/or oleic acid concentration used and all measurements were performed in duplicate.

\section{The effect of cycloheximide on the accumulation of mRNA}

To examine the role of de novo protein synthesis under the different experimental settings, HepG2 cells grown to about $80 \%$ confluence were further incubated under zero or normal glucose without or with $0.3 \mathrm{mmol} / 1$ oleic acid and without or with $1.4 \mu \mathrm{g} / \mathrm{ml}$ translational inhibitor cycloheximide. After $4 \mathrm{~h}$, total RNA was isolated from the cells and mRNA levels were measured by real-time RT-PCR, as described below.

\section{The effect of actinomycin D on the stability of mRNA}

For mRNA stability studies, HepG2 cells grown to about $80 \%$ subconfluence were further incubated under zero or normal glucose without or with $0.3 \mathrm{mmol} / 1$ oleic acid for $3 \mathrm{~h}$. After $3 \mathrm{~h}$, transcriptional inhibitor actinomycin $\mathrm{D}(4 \mu \mathrm{g} / \mathrm{ml})$ was added to one set of target samples to stop mRNA transcription for another $1 \mathrm{~h}$. Another set of 
target samples was treated with the combination of both actinomycin $\mathrm{D}(4 \mu \mathrm{g} / \mathrm{ml})$ and cycloheximide $(1.4 \mu \mathrm{g} / \mathrm{ml})$. Control cells were maintained untreated with the inhibitors for the same $1 \mathrm{~h}$ time interval. After $1 \mathrm{~h}$, total RNA was isolated from the cells and mRNA levels were measured by real-time RT-PCR, as described below.

\section{Quantitative real-time RT-PCR for mRNA analysis}

Quantitative real-time PCR was performed to measure the mRNA levels of the studied genes using the rapid thermal LightCycler system (Roche Diagnostics, Mannheim, Germany). Total RNA was extracted from $10^{6}$ cells using the High Pure RNA Isolation kit, and mRNA was reversetranscribed using the Transcriptor First Strand cDNA Synthesis kit (both kits from Roche). Primers (Tab. 1) were designed using the NCBI nucleotide database and LightCycler Probe Design software (HPRT primers) or adopted according to the data of others and were synthesized by Metabion International (Martinsried, Germany). Twenty microliters of a reaction mixture consisting of FastStart DNA MasterPLUS SYBR Green I (Roche), the forward and reverse primers $(0.5 \mu \mathrm{mol} / 1$ each $)$, and an aliquot of the reverse-transcribed samples $(2 \mu \mathrm{l})$ were contained in a LightCycler glass capillary. Negative controls were tested in parallel. The quality of the PCR products detected with SYBR green was routinely confirmed by melting curve analysis and, in initial experiments, by agarose gel electrophoresis using ChemiGenius System computerized densitometry (Syngene, Cambridge, UK).

\section{Relative mRNA quantification and statistical evaluation}

A normalization factor derived from multiple reference genes (Tab. 1) measured in the same RNA sample was used to compute the relative expression ratio ${ }^{22}$. Three separate experiments were performed, and each determination was executed in duplicate. The PCR data characterizing the relative mRNA expression levels in target samples were compared to the corresponding values for controls using $t$-test and, within groups, ANOVA and LSD post hoc test. The results presented in the text and the figures correspond to mean $\pm \mathrm{SD}$ values. The statistical significance was set at $\mathrm{p}<0.05$.

\section{RESULTS}

Effects of glucose deprivation and oleate on $m R N A$ levels. Using quantitative real-time RT-PCR we first studied the effects of $0.5 \mathrm{~h}$ and $4 \mathrm{~h}$ incubations with zero or normal ( $5 \mathrm{mmol} / \mathrm{l}$ ) concentrations of glucose and/or oleic acid $(0.3 \mathrm{mmol} / \mathrm{l})$ on mRNA expression of several molecular species functionally allied to PPAR transcriptional factors in HepG2 cells. In figure 1, relative mRNA levels of PPAR- $\alpha,-\gamma 1,-\gamma 2$, and PGC- $1 \alpha$ and $-1 \beta$ determined in duplicate assays from three independent experiments were compared to the control mRNA levels of the same molecules when cells were maintained under normal glucose without oleate (the basal state) during the early incubation period. At the end of this period, there was a modest but significant elevation in PGC- $1 \alpha$ mRNA level in HepG 2 cells maintained in the absence of both glucose and oleate ( $123 \%$ of the control level; $p<0.05$ ) (Fig. 1). Furthermore, significant increase in PGC-1 $\beta$ mRNA levels could be seen during the early incubation period brought about by $0.3 \mathrm{mmol} / 1$ oleate $(134 \%$ and $160 \%$ of control levels for zero glucose plus oleate and normal glucose plus oleate, respectively; $p<0.05$ for each) (Fig. 1). All together these findings indicated that during the early incubation period, PGC- $1 \alpha$ mRNA abundance was significantly upregulated in the absence of glucose, while PGC-1 $\beta$ mRNA content was significantly enhanced in the cells by oleate, irrespective of glucose concentrations. No significant change in PPAR mRNAs was detected in this early period.

We next measured the relative mRNA levels in target samples during the prolonged incubation period $(4 \mathrm{~h})$. From figure 2 it is obvious that at the end of this incubation, PPAR- $\gamma 1$ and PGC- $1 \alpha$ mRNA levels were significantly elevated in glucose-oleate-starved samples compared with the control (basal) state (142\% and $163 \%$ of control levels, respectively; $\mathrm{p}<0.05$ for each). This zero glucoseinduced elevation in PPAR- $\gamma 1$ and PGC- $1 \alpha$ mRNAs was also significant upon the administration of $0.3 \mathrm{mmol} / 1$ oleate ( $132 \%$ and $131 \%$ of control levels, respectively; $\mathrm{p}<0.05$ for each) (Fig. 2). In contrast, oleate significantly suppressed PPAR- $\alpha$ and PGC-1 $\beta$ mRNA levels in

Table 1. Primers used for quantitative real-time PCR analyses.

\begin{tabular}{|c|c|c|c|}
\hline & Forward primer $\left(5^{c}-3^{c}\right)$ & Reverse primer $\left(5^{\circ}-3^{\circ}\right)$ & Ref. \\
\hline \multicolumn{4}{|c|}{ Target } \\
\hline PPAR $\gamma 1$ & AAAGAAGCCGACACTAAACC & CTTCCATTACGGAGAGATCC & 17 \\
\hline PPAR $\gamma 2$ & GCGATTCCTTCACTGATAC & CTTCCATTACGGAGAGATCC & 17 \\
\hline PPAR $\alpha$ & ACTTATCCTGTGGTCCCCGG & CCGACAGAAAGGCACTTGTGA & 18 \\
\hline PGC1 $\alpha$ & TGTGCAACTCTCTGGAACTG & TGAGGACTTGCTGAGTGGTG & 19 \\
\hline PGC1 $\beta$ & GCTCTCСТССТTCTTCСТCA & ATAGAGCGTCTCCACCATCC & 19 \\
\hline \multicolumn{4}{|c|}{ Reference } \\
\hline CynA & GCATACGGGTCCTGGCATCTTGTCC & ATGGTGATCTTCTTGCTGGTCTTGC & 20 \\
\hline GAPDH & ACCACAGTCCATGCCATCAC & TCCACCACCATGTTGCTGTA & 21 \\
\hline HPRT & GGACTGAACGTCTTGC & CTTCGTGGGGTCCTTT & - \\
\hline
\end{tabular}




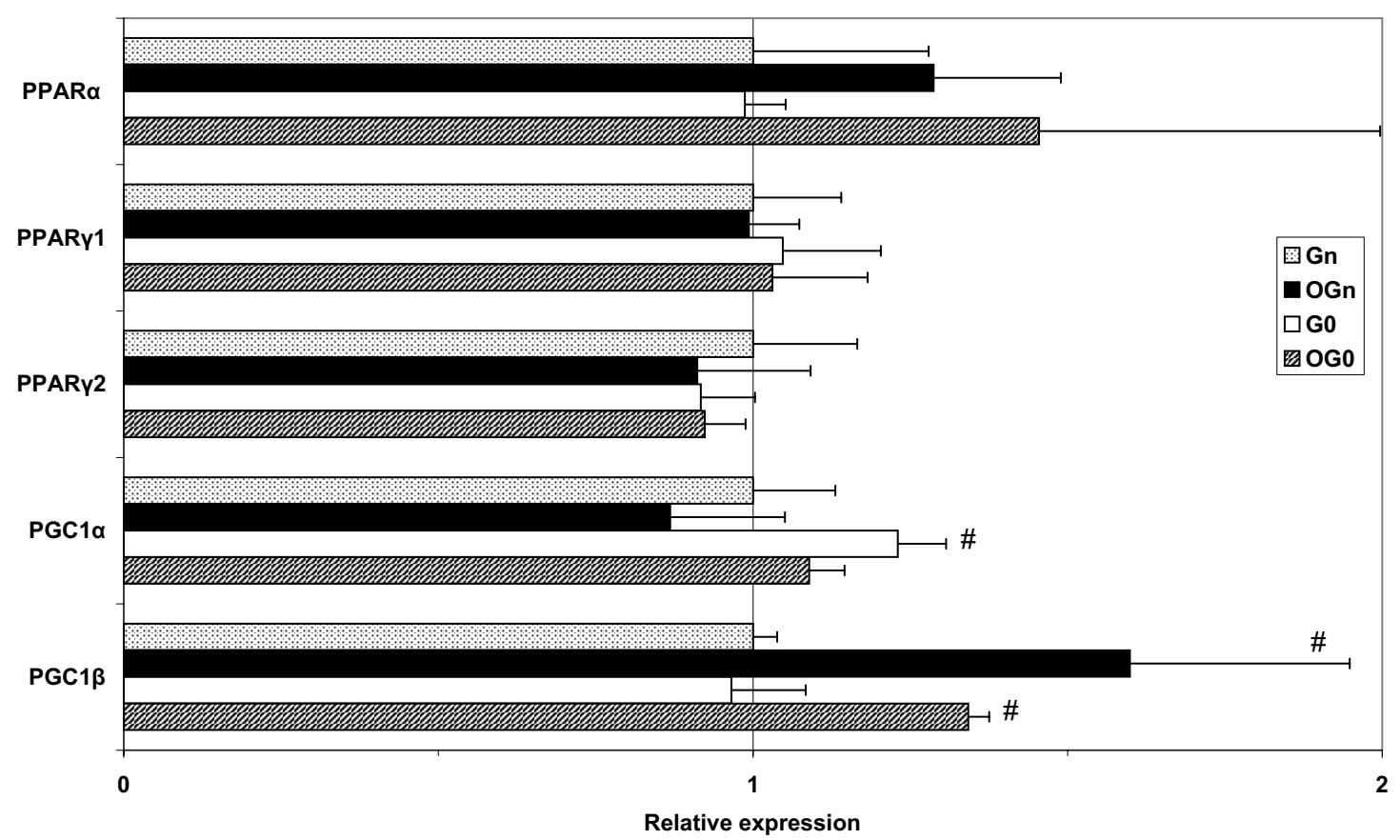

Fig. 1. Effects of glucose deprivation and oleate on mRNA levels of PPAR-allied signalling molecules in HepG2 cells upon $0.5 \mathrm{~h}$ incubation. HepG 2 cells were incubated with normal $(5 \mathrm{mmol} / \mathrm{l})$ concentration of glucose (Gn), normal glucose and $0.3 \mathrm{mmol} / 1$ oleate (OGn), zero glucose (G0), and/or zero glucose and $0.3 \mathrm{mmol} / 1$ oleate (OG0) for $0.5 \mathrm{~h}$, and real-time RT-PCR was performed to quantify mRNA levels. The incubation with normal glucose without oleate served as a control. Mean relative mRNA expression levels of target genes were expressed as a fold-increase compared to the control. Three independent experiments were performed for each treatment and each determination was executed in duplicate. \# denotes significant difference $(\mathrm{p}<$ 0.05 ) when target and control cells were compared using $t$-test.

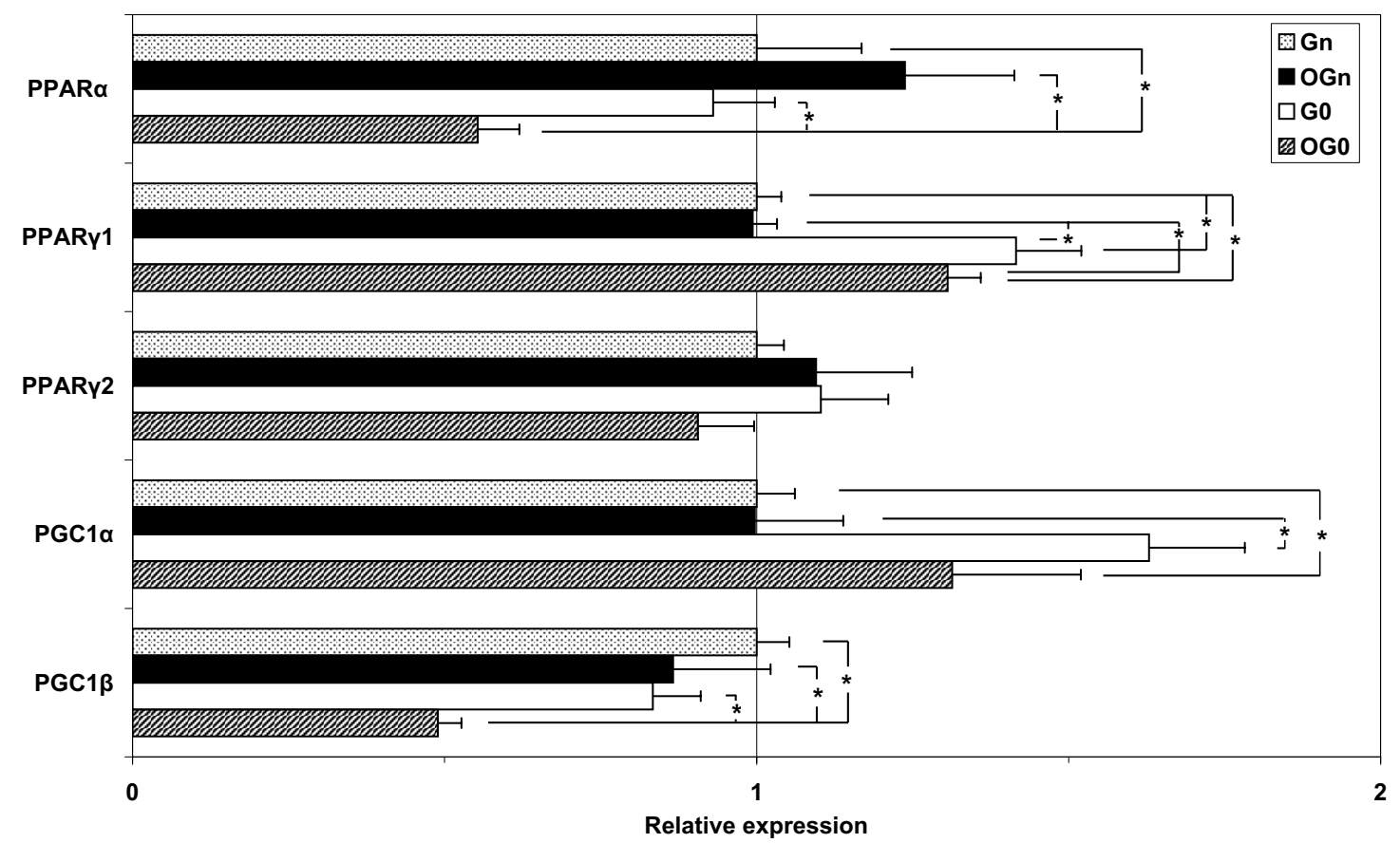

Fig. 2. Effects of glucose deprivation and oleate on mRNA levels of PPAR-allied signalling molecules in HepG2 cells upon $4 \mathrm{~h}$ incubation. HepG2 cells were incubated with normal $(5 \mathrm{mmol} / \mathrm{l})$ concentration of glucose $(\mathbf{G n})$, normal glucose and $0.3 \mathrm{mmol} / 1$ oleate (OGn), zero glucose (G0), and/or zero glucose and $0.3 \mathrm{mmol} / 1$ oleate (OG0) for $4 \mathrm{~h}$, and real-time RT-PCR was performed to quantify mRNA levels. The incubation with normal glucose without oleate served as a control. Mean relative mRNA expression levels of target genes were expressed as a fold-increase compared to the control. Three independent experiments were performed for each treatment and each determination was executed in duplicate. * denotes significant difference $(p<0.05)$ for within group variance analyzed by ANOVA with post hoc significance test. 
glucose-deprived cells ( $58 \%$ and $49 \%$ of control levels, respectively; $p<0.05$ for each) (Fig. 2). Finally, PPAR- $\gamma 2$ mRNA levels varied only insignificantly at the end of the $4 \mathrm{~h}$ period (Fig. 2).

The dependence of $m R N A$ content on de novo protein synthesis. To get further insight into the molecular mechanisms of the above effects, we asked whether these effects were dependent on de novo synthesis of proteins. To investigate this, the cells were incubated in the presence or the absence (control) of translational inhibitor cycloheximide $(1.4 \mu \mathrm{g} / \mathrm{ml}, 4 \mathrm{~h})$. From RT-PCR analyses of duplicate assays from three independent experiments in figure 3 it is apparent that in all experimental settings, PPAR- $\gamma 2$ mRNA level was significantly superinduced in cells by administration of cycloheximide, both in the absence and the presence of oleate. More specifically, upon cycloheximide treatment, PPAR- $\gamma 2$ mRNA was elevated to about the same extent in zero and normal glucose settings ( $353 \%$ and $388 \%$ of control levels, respectively; $p<0.05$ for each) (Fig. 3). The presence of oleate did not preclude these elevations (303\% and $356 \%$ of control levels for zero glucose plus oleate and normal glucose plus oleate, respectively; $\mathrm{p}<0.05$ for each) (Fig. 3). Also significantly superinduced by cycloheximide, albeit to a lesser extent, were the PPAR- $\gamma 1$ mRNA levels in cells maintained in normal glucose settings, both in the absence and the presence of oleate (124\% and $125 \%$ of control levels, respectively; $p<0.05$ ) (Fig. 3). In contrast, cycloheximide significantly suppressed PPAR- $\alpha$ mRNA content in zero glucose and normal glucose-oleate samples ( $43 \%$ and $54 \%$ of control levels, respectively; $\mathrm{p}<0.05)$. The decrease in PPAR- $\alpha$ mRNA level caused by cycloheximide in zero glucose plus oleate and normal glucose samples did not reach statistical significance $(77 \%$ and $71 \%$ of control levels, respectively) (Fig. 3). Furthermore, PGC$1 \alpha$ mRNA was consistently reduced upon cycloheximide administration in all experimental settings (42\%, $44 \%$, $47 \%$, and $51 \%$ of control levels for zero glucose, zero glucose plus oleate, normal glucose, and normal glucose plus oleate, respectively; $p<0.05$ ) (Fig. 3). Also PGC-1 $\beta$ mRNA levels were reduced by the presence of cycloheximide in all experimental batches $(73 \%, 77 \%, 57 \%$, and $76 \%$ of control levels for zero glucose, zero glucose plus oleate, normal glucose, and normal glucose plus oleate, respectively; $\mathrm{p}<0.05$ ) (Fig. ). These findings indicated that with the exception for PPAR- $\gamma 1$ mRNA in glucose-deprived cells, both PPAR- $\gamma$ mRNAs were superinduced in the absence of de novo protein synthesis, whereas PPAR$\alpha$ and PGC- $1 \alpha$ and- $1 \beta$ mRNAs required de novo protein synthesis for their integrity.

Actinomycin $D$ effects. Considering that the amount of mRNAs can be regulated by both transcriptional and posttranscriptional mechanisms, we asked whether the turnover of the studied mRNAs was affected in the cells. In preliminary experiments, we had estimated that decay rates for most studied mRNAs were higher in the first 2.0-2.5 hours following administration of actinomycin $\mathrm{D}$, which was added to block new transcription, than in the later period (data not shown). Then, to investigate
mRNA turnover, the cells were incubated for $3 \mathrm{~h}$ to induce changes in mRNA levels (control, $100 \%$ ) and then the rate of decline of mature mRNAs was estimated upon $1 \mathrm{~h}$ treatment of the cells with actinomycin $\mathrm{D}(4 \mu \mathrm{g} / \mathrm{ml})$. Concurrently, actinomycin D was used together with cycloheximide to reveal the combined effects of these inhibitors. The results of duplicate assays from three independent experiments were plotted in figure 4. First, from the PPAR- $\alpha$ mRNA decay data it can be seen that in the presence of actinomycin D alone, PPAR- $\alpha$ mRNA decreased faster in cells incubated under normal glucose than in glucose-deprived cells (56\% of the control level for normal glucose vs. $99 \%$ of the control level for zero glucose). The difference achieved significance when the incubation media were supplemented with oleate $(47 \%$ of the control level for normal glucose-oleate vs. $93 \%$ of the control level for zero glucose plus oleate; $p<0.05$ ) (Fig. 4). This finding indicates that glucose shortage stabilized PPAR- $\alpha$ mRNA in comparison to normal glucose concentration. Moreover, when actinomycin D was used together with cycloheximide, we observed mild to strong upregulation of PPAR- $\alpha$ mRNA content in all cell batches (129\%, $207 \%, 180 \%$, and $149 \%$ of control levels for zero glucose-actinomycin D-cycloheximide, zero glucose-oleate-actinomycin D-cycloheximide, normal glucose-actinomycin D-cycloheximide, and normal glucose-oleate-actinomycin D-cycloheximide, respectively). In all but the first of these, this upregulation achieved statistical significance when the samples were compared with their counterparts incubated without cycloheximide $(p<0.05)$ (Fig. 4). Second, following actinomycin D treatment of glucose-deprived cells, PGC- $1 \alpha$ mRNA amount was significantly lower in cells supplemented with oleate ( $60 \%$ of the control level) than in those incubated in its absence (77\% of the control level), suggesting that PGC-1 $\alpha$ mRNA was destabilized in glucose-deprived, oleate-treated cells ( $p<0.05$ ) (Fig. 4). Finally, we found that upon $1 \mathrm{~h}$ actinomycin $\mathrm{D}$ or actinomycin D-cycloheximide administration, basal PPAR- $\gamma 1,-\gamma 2$, and PGC- $1 \beta$ mRNA levels were about $80 \pm 18 \%, 85 \pm 32 \%$, and $70 \pm 16 \%$ and were not significantly affected by the presence or absence of glucose and/or oleate. Notably, in contrast to the above findings, no significant PPAR- $\gamma$ mRNA superinduction was observed when actinomycin $\mathrm{D}$ was combined with cycloheximide during this $1 \mathrm{~h}$ incubation period (data not shown).

\section{DISCUSSION}

Steady state levels of mRNA are the outcome of mutually antagonistic processes of mRNA synthesis and degradation. It is now increasingly appreciated that the control of these processes functions as a powerful mechanism for regulating gene activity. In this article, we provide evidence for the regulation of mRNA expression of several members of the PPAR signaling machinery by abundant dietary and plasma substrates, glucose and oleate. Notably, mRNA expression of PPAR- $\alpha,-\gamma 1$, and $-\gamma 2$ and PPAR- $\gamma$ 


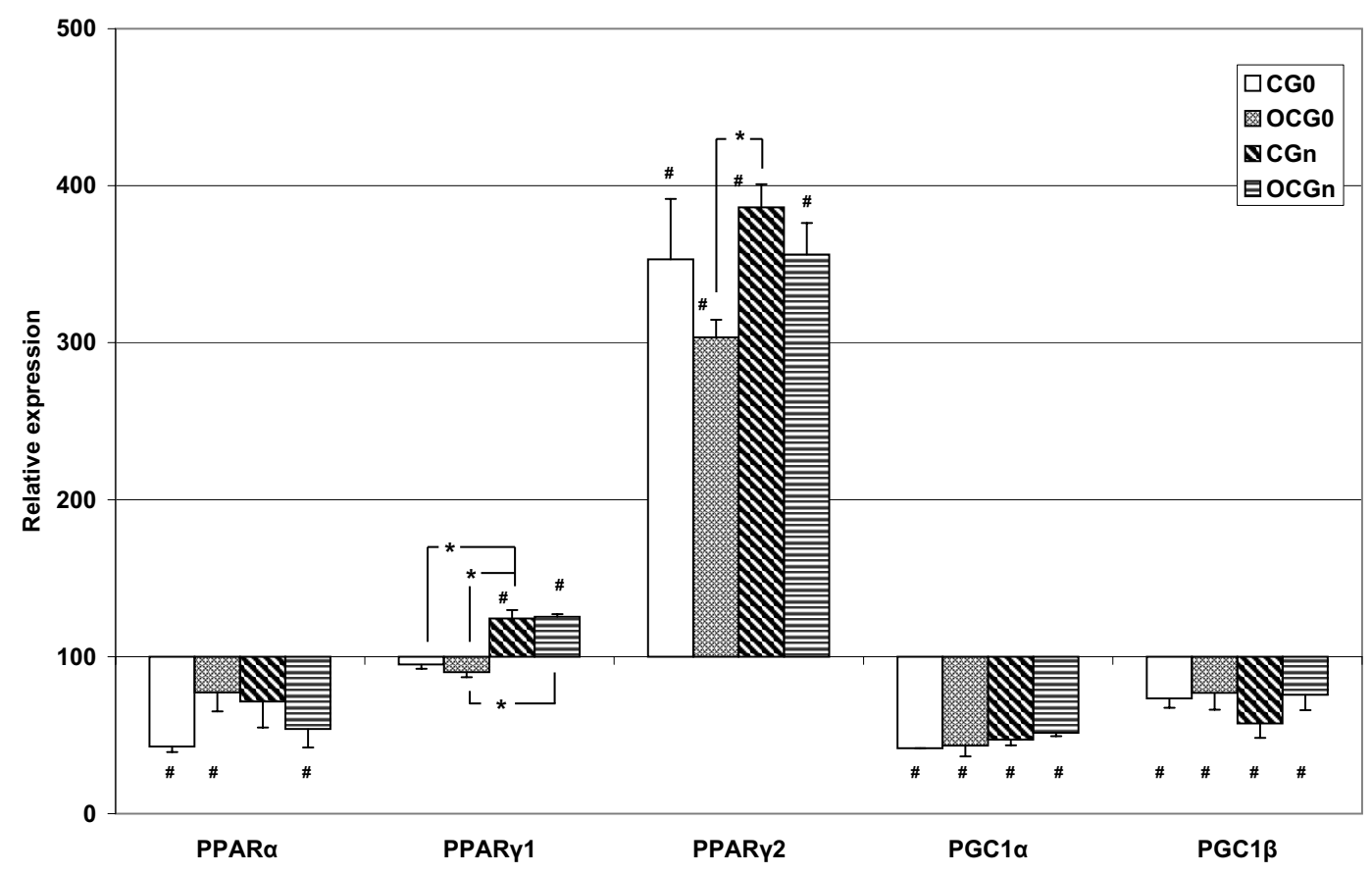

Fig. 3. Effects of glucose deprivation and oleate on mRNA levels of PPAR-allied signalling molecules in HepG2 in the presence of cycloheximide. HepG2 cells were incubated with zero glucose $(\mathbf{G 0})$, zero glucose and 0.3 $\mathrm{mmol} / 1$ oleate (OG0), normal ( $5 \mathrm{mmol} / \mathrm{l}$ ) concentration of glucose $(\mathbf{G n})$, and/or normal glucose and 0.3 $\mathrm{mmol} / \mathrm{l}$ oleate (OGn) for $4 \mathrm{~h}$ in the absence (controls) and presence of $1.4 \mu \mathrm{g} / \mathrm{ml}$ cycloheximide (C), and real-time RT-PCR was performed to quantify mRNA levels. Control mRNA levels without cycloheximide were defined as $100 \%$, and mRNA levels in samples were calculated as percentage of this value. Three independent experiments were performed for each treatment and each determination was executed in duplicate. \# denotes significant difference $(\mathrm{p}<0.05)$ when target and control cells were compared using $t$-test. * denotes significant difference $(p<0.05)$ for within group variance analyzed by ANOVA with post hoc significance test.

coactivators PGC-1 $\alpha$ and $-1 \beta$ has been affected in HepG2 cells by exogenous substrates in the absence of variation in the ambient hormonal milieu of the cells ${ }^{1,8,9}$.

PPAR intracellular transcriptional factors are situated at the core of the cellular control of energy status. Recently it has been shown that in addition to its important role in fatty acid metabolism, PPAR- $\alpha$ can upregulate the genes involved in hepatic gluconeogenesis. Accordingly, PPAR- $\alpha$ has been ascribed a pivotal role in the adaptive response to fasting ${ }^{23-26}$. In HepG2 cells incubated in the presence of $10 \%$ FBS and normal glucose, Fujiwara et al. (2003) found 1.4 fold reduction in PPAR$\alpha$ mRNA content following $24 \mathrm{~h}$ treatment of the cells with $0.25 \mathrm{mmol} / 1$ oleate $^{27}$. In our study, hormonal stimulation of cells that normally regulate fed- to fasted-state transition was avoided. We detected significant decline in PPAR- $\alpha$ mRNA level upon prolonged ( $4 \mathrm{~h}$ ) incubation of HepG2 cells in medium lacking glucose but containing $0.3 \mathrm{mmol} / 1$ oleate. This effect was absent in cells maintained under normal glucose (Fig. 2). The differences between the model used by Fujiwara et al. (2003) (ref. ${ }^{27}$ ) and ours are likely to explain these conflicting findings. We have further demonstrated that PPAR- $\alpha$ mRNA stability is dependent on de novo protein synthesis and elevated in glucose-deprived, actinomycin D-treated cells. At the same time, we have shown that PPAR- $\alpha$ mRNA is super- induced by cycloheximide in cells when transcription is blocked. More experiments are clearly needed to resolve this puzzle. However, it is appropriate to mention that rather enigmatic mRNA superinduction in the absence of transcription is not exceptional. For instance, it has been also described in a study focused on PGC-1-related coactivator (PRC) variations during cell cycling ${ }^{28}$.

In addition to PPAR- $\alpha$, both PPAR- $\gamma 1$ and $-\gamma 2$ proteins are detectable in the liver, despite relatively low mRNA levels of these proteins in cells of hepatic ori$\operatorname{gin}^{29}$. According to the present study, PPAR- $\gamma 1 \mathrm{mRNA}$ significantly increased in HepG2 cells maintained for four hours in a medium lacking glucose, while PPAR- $\gamma 2$ mRNA did not. The PPAR- $\gamma 1$ mRNA elevation is also apparent in glucose-deprived cells in the presence of oleate, whereas no significant effect of oleate on PPAR- $\gamma 2$ mRNA is observable (Fig. 2). In comparison, in the above mentioned study, Fujiwara et al. (2003) detected stimulation of PPAR- $\gamma$ mRNA expression (isoform not specified) in HepG 2 cells following $24 \mathrm{~h}$ oleate treatment ${ }^{27}$. In a recent study by Edvardsson et al. (2006) isolated mouse hepatocytes maintained with $0.5 \mathrm{mmol} / 1$ oleate (in the presence of $0.75 \%$ albumin and $11 \mathrm{mmol} / 1$ glucose) were markedly upregulated PPAR- $\gamma 2$ mRNA amount, whereas that of PPAR- $\gamma 1$ mRNA remained unchanged ${ }^{30}$. Species and model variations are likely to be taken into account to un- 


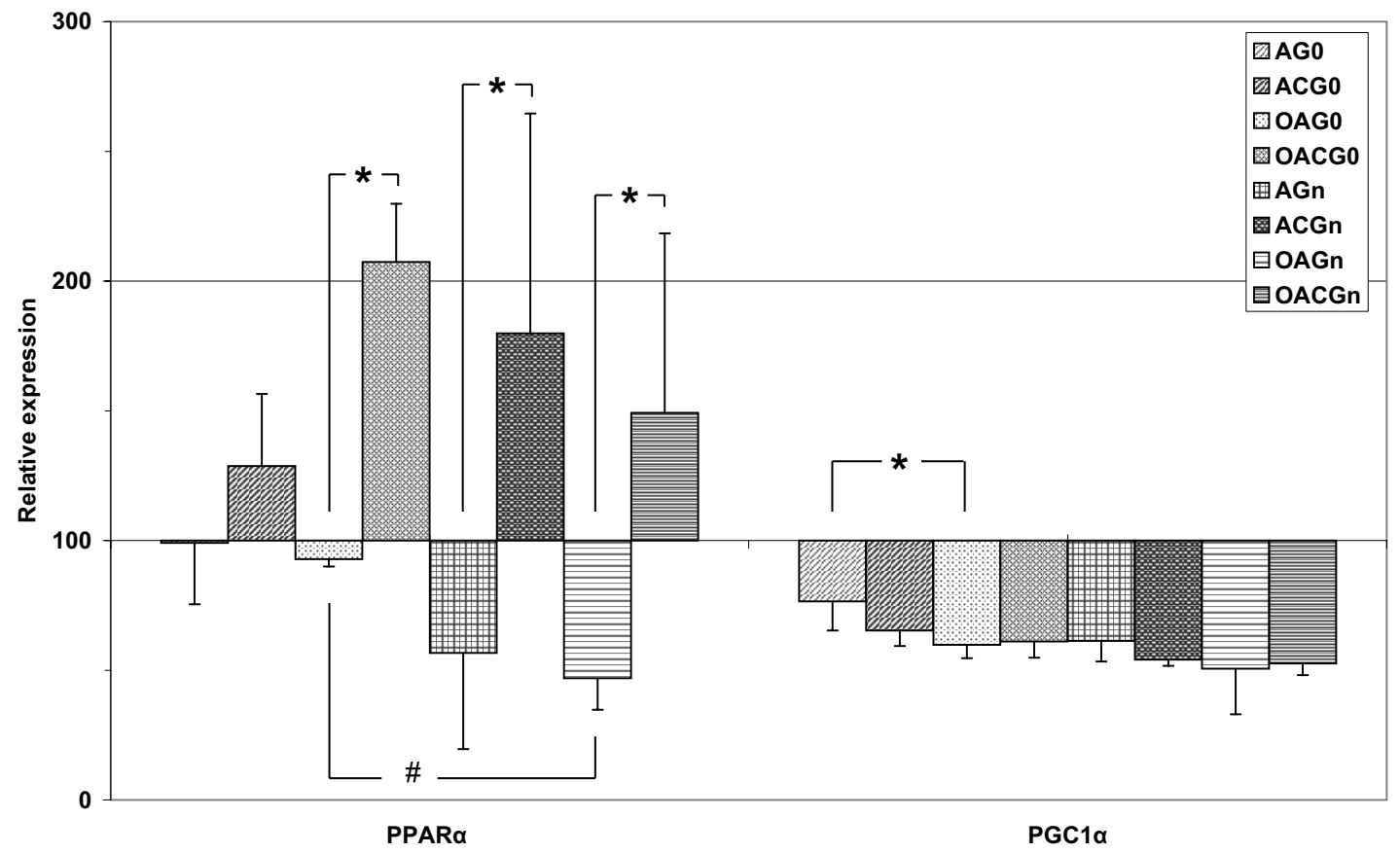

Fig. 4. Effects of glucose deprivation and oleate on mRNA stability in the presence of actinomycin $\mathrm{D}$ and in the presence of a combination of actinomycin D with cycloheximide. HepG2 cells were pre-incubated for $3 \mathrm{~h}$ with normal $(5 \mathrm{mmol} / 1)$ glucose $(\mathbf{G n})$, normal glucose and $0.3 \mathrm{mmol} / 1$ oleate $(\mathbf{O G n})$, zero glucose $(\mathbf{G 0})$, or zero glucose and $0.3 \mathrm{mmol} / 1$ oleate (OG0) to induce changes in mRNA levels (controls) and then changes in amount of mature mRNAs were estimated upon $1 \mathrm{~h}$ treatment of the cells with $4 \mu \mathrm{g} / \mathrm{ml}$ actinomycin D (A). Concurrently, $4 \mu \mathrm{g} / \mathrm{ml}$ actinomycin D together with $1.4 \mu \mathrm{g} / \mathrm{ml}$ cycloheximide (AC) was used to reveal combined effects of these inhibitors. At the end of incubation, the cells were harvested, and mRNAs were analyzed by real-time RT-PCR. Control mRNA levels at the end of the $3 \mathrm{~h}$ pre-incubation were defined as $100 \%$, and mRNA levels in samples were calculated as percentage of this value. Three independent experiments were performed for each treatment and each determination was executed in duplicate. \# denotes significant difference $(\mathrm{p}<0.05)$ when target and control cells were compared using $t$-test. * denotes significant difference $(\mathrm{p}<0.05)$ for within group variance analyzed by ANOVA with post hoc significance test.

derstand the cause of these discrepancies. Administration of translational inhibitor cycloheximide in the present work revealed strong PPAR- $\gamma 2$ mRNA superinduction in both glucose-fed and glucose-deprived cells, whereas superinduction of PPAR- $\gamma 1$ was modest and only detectable in the presence of glucose, indicating that PPAR- $\gamma 1$ and $-\gamma 2$ mRNA transcripts are differently regulated in normal glucose and zero-glucose settings (Fig. 3). This further stresses that the precise roles of the control of the expression of these two isoforms in mediating PPAR- $\gamma$ functions in cells remain to be defined.

PGC- $1 \alpha$ and $-1 \beta$ have been implicated by previous authors as the key ligand-independent coactivators of PPARs as well as many other nuclear receptors. Studies on PGC1 suggest that they are tightly regulated in a tissue-specific manner. Relevantly, both these isoforms have been found to be markedly elevated in fasted liver. PGC-1 $\alpha$ controls mitochondrial energy metabolism and stimulates gluconeogenesis ${ }^{6,7,31}$. The present increase in PGC-1 $\alpha$ mRNA in HepG2 cells incubated in the absence of glucose, both without and with oleate, is fully consonant with both, the pro-oxidative and gluconeogenic PGC- $1 \alpha$ functions of PGC-1 $\alpha$. Notably, PGC- $1 \alpha$ mRNA is the only one of the explored mRNAs that was significantly upregulated in both the early $(0.5 \mathrm{~h})$ and prolonged $(4 \mathrm{~h})$ incubation periods. Moreover, this increase was induced in HepG2 cells by glucose deprivation per se, i.e. in the absence of exogenous stimulation of the cells by glucorticoids or hormones that physiologically activate PGC- $1 \alpha$ via the cAMP pathway. Presumably, the persistent abundance of PGC- $1 \alpha$ mRNA in cells lacking glucose and treated with oleate (Fig. 2) may be related to combined PGC$1 \alpha$ stimulatory gluconeogenic and $\beta$-oxidation effects ${ }^{32}$. PGC- $1 \alpha$ has been also reported to interact with PPAR- $\alpha$ to maintain constitutive fatty acid oxidation ${ }^{6,7,31}$. However, in neither the early nor prolonged time periods did the significant changes in PGC- $1 \alpha$ mRNA levels, observed by us, correlated with those of PPAR- $\alpha$ mRNA. This finding supports that although PGC- $1 \alpha$ and PPAR- $\alpha$ may closely cooperate in regulating oxidative and gluconeogenic processes, the link between them is not simply linear. For instance, it is well known that stimulation of PPAR- $\alpha$ by its pharmacological agonists can improve impaired insulin sensitivity, whereas PGC-1 $\alpha$ overexpression in the liver contributes to hyperglycaemia associated with insulin resistance and diabetes mellitus ${ }^{3-5,9}$. 
We have demonstrated that PGC-1 $\beta$ mRNA content is significantly enhanced in HepG2 cells by oleate, irrespective of glucose concentrations, in the early $(0.5 \mathrm{~h})$ incubation period. However, in contrast to PGC-1 $\alpha$, this PGC-1 $\beta$ mRNA burst is only transient since it did not persist with the prolonged $(4 \mathrm{~h})$ incubation period. Moreover, oleate significantly suppressed the PGC- $1 \beta$ mRNA level during the prolonged incubation in the absence of glucose. Supposedly, this relatively rapid drop in PGC-1 $\beta$ mRNA level is understandable since PGC-1 $\beta$ functions as an effective coactivator of the genes involved in lipogenesis and lipoprotein secretion, rather than an activator of gluconeogenic genes ${ }^{6,7}$. However, more work is clearly needed to elucidate the molecular mechanisms behind the biological action of the two PGCs. Notably, the present study reveals the decline in PGC-1 $\beta$ mRNA levels after the $4 \mathrm{~h}$ administration of cycloheximide, implying that this mRNA may require de novo protein synthesis to supply it with one or more positive mRNA-stability regulator(s) for its integrity.

\section{CONCLUSIONS}

In conclusion, this paper provides evidence for the effects of glucose deprivation and/or oleate administered at near-physiological levels on mRNA content, in Hep G2 cells, of several regulatory components associated with the PPAR-dependent signalling machinery, known to play critical roles in a number of both physiological and pathological states. Significantly, the changes in mRNA content were elicited by nutrient variations without alteration in the ambient hormonal milieu of the cells. Our findings suggest that the transcriptional processes generating the investigated mRNAs to be interconnected with concurrent translational processes that can either destabilize, or stabilize mRNAs. Whether the changes in mRNA levels project into the activity of appropriate proteins remains to be explored. Our findings open way for designing experiments to unravel the processes behind the new observations.

\section{LIST OF ABBREVIATIONS}

$\begin{array}{ll}\text { BSA } & \text { bovine serum albumin } \\ \text { CynA } & \text { cyclophilin A } \\ \text { EMEM } & \text { Eagle's minimum essential medium } \\ \text { FBS } & \text { fetal bovine serum } \\ \text { GAPDH } & \text { glyceraldehyde-3-phosphate dehydrogenase } \\ \text { HPRT } & \text { hypoxanthine phosphoribosyltransferase } \\ \text { PPAR } & \text { peroxisome proliferator-activated receptor } \\ \text { PGC } & \text { PPAR- } \gamma \text { coactivator }\end{array}$

RT-PCR reverse transcription-polymerase chain reaction.

\section{ACKNOWLEDGMENTS}

This work was supported in part by the Ministry of Education, Youth, and Sports, Czech Republic, grant MSM 6198959205, by the European Cooperation in the Field of Science and Technology (COST) grant COST B35, and by Medical Faculty, Palacký University grant support.

The authors declare that there is no conflict of interest that would prejudice the impartiality of this scientific work.

\section{REFERENCES}

1. Desvergne B, Michalik L, Wahli W. Transcriptional Regulation of Metabolism. Physiol Rev. 2006; 86:465-514.

2. Duplus E, Forest C. Is there a single mechanism for fatty acid regulation of gene transcription? Biochem Pharmacol. 2002; 64:893-901.

3. Ferré P. The biology of peroxisome proliferator-activated receptors. Relationship with lipid metabolism and insulin sensitivity. Diabetes. 2004; 53(Suppl 1):S43-50.

4. Francis GA, Fayard E, Picard F, Auwerx J. Nuclear receptors and the control of metabolism. Annu Rev Physiol. 2003; 65:261-311.

5. Lefebvre P, Chinetti G, Fruchart JC, Staels B. Sorting out the roles of PPAR $\alpha$ in energy metabolism and vascular homeostasis. J Clin Invest. 2006; 116:571-80.

6. Finck BN, Kelly DP. PGC-1 coactivators: inducible regulators of energy metabolism in health and disease. J Clin Invest. 2006; 116:615-22.

7. Lin J, Handschin C, Spiegelman BM. Metabolic control through the PGC-1 family of transcription coactivators. Cell Metabol. 2005; 1:361-70.

8. Herzig S, Long F, Jhala US, Hedrick S, Quinn R, Bauer A et al. CREB regulates hepatic gluconeogenesis through the coactivator PGC-1. Nature. 2001; 413:179-83.

9. Yoon JC, Puigserver P, Chen G, Donovan J, Wu Z, Rhee J et al. Control of hepatic gluconeogenesis through the transcriptional coactivator PGC-1. Nature. 2001; 413:131-38.

10. Koo SH, Satoh H, Herzig S, Lee CH, Hedrick S, Kulkarni R et al. PGC-1 promotes insulin resistance in liver through PPAR-alphadependent induction of TRB-3. Nat Med. 2004; 10:530-4.

11. Leone TC, Lehman JJ, Finck BN, Schaeffer PJ, Wende AR, Boudina $\mathrm{S}$ et al. PGC-1alpha deficiency causes multisystem energy metabolic derangements: muscle dysfunction, abnormal weight control and hepatic steatosis. PLoS Biol. 2005; 3:e101.

12. Lin J, Wu PH, Tarr PT, Lindenberg KS, St-Pierre J, Zhang CY et al. Defects in adaptive energy metabolism with CNS-linked hyperactivity in PGC-1alpha null mice. Cell. 2004; 119:121-35.

13. Ross J. mRNA Stability in mammalian cells. Microbiol Rev. 1995; 59:423-50.

14. Mootha VK, Lindgren CM, Eriksson KF, Subramanian A, Sihag $\mathrm{S}$, Lehar $\mathrm{J}$ et al. PGC-1alpha-responsive genes involved in oxidative phosphorylation are coordinately downregulated in human diabetes. Nat Genet. 2003; 34:267- 73.

15. Patti ME, Butte AJ, Crunkhorn S, Cusi K, Berria R, Kashyap S et al. Coordinated reduction of genes of oxidative metabolism in humans with insulin resistance and diabetes: potential role of PGC1 and NRF1. Proc Natl Acad Sci U S A. 2003; 100:8466-71.

16. Roden M. Muscle triglycerides and mitochondrial function: possible mechanisms for the development of type 2 diabetes. Int $\mathbf{J}$ Obes (Lond). 2005; 29 Suppl 2: S111-5.

17. Giusti V, Verdumo C, Suter M, Gaillard RC, Burckhardt P, Pralong F. Expression of peroxisome proliferator-activated receptor-gamma1 and peroxisome proliferator-activated receptor-gamma 2 in visceral and subcutaneous adipose tissue of obese women. Diabetes. 2003; 52:1673-6.

18. Liu DC, Zang CB, Liu HY, Possinger K, Fan SG, Elstner E. A novel PPAR alpha/gamma dual agonist inhibits cell growth and induces 
apoptosis in human glioblastoma T98G cells. Acta Pharmacol Sin 2004; 25:1312-9.

19. Staiger H, Staiger K, Haas C, Weisser M, Machicao F, Haring HU. Fatty acid-induced differential regulation of the genes encoding peroxisome proliferator-activated receptor-gamma coactivator1alpha and -1beta in human skeletal muscle cells that have been differentiated in vitro. Diabetologia. 2005; 48:2115-8.

20. Blanquart C, Mansouri R, Paumelle R, Fruchart JC, Staels B, Glineur $\mathrm{C}$. The protein kinase $\mathrm{C}$ signalling pathway regulates a molecular switch between transactivation and transrepression activity of the peroxisome proliferator-activated receptor alpha (PPAR $\alpha)$. Mol Endocrinol. 2004; 18:1906-18.

21. Kemp TJ, Causton HC, Clerk A. Changes in gene expression induced by $\mathrm{H}(2) \mathrm{O}(2)$ in cardiac myocytes. Biochem Biophys Res Commun. 2003; 307:416-21.

22. Bustin SA, Benes V, Nolan T, Pfaffl MW. Quantitative real-time RT-PCR - a perspective. J Mol Endocrinol. 2005; 34:597-601.

23. Hashimoto T, Cook WS, Qi C, Yeldandi AJ, Reddy JK, Rao MS. Defect in peroxisome proliferator-activated receptor $\alpha$-inducible fatty acid oxidation determines the severity of hepatic steatosis in response to fasting. J Biol Chem. 2000; 275:28918-28.

24. Hsu MH, Savas U, Griffin KJ, Johnson EF. Identification of Peroxisome Proliferator-responsive Human Genes by Elevated Expression of the Peroxisome Proliferator-activated Receptor $\alpha$ in HepG2 Cells. J Biol Chem. 2001; 276:27950-8.

25. Kersten S, Seydoux J, Peters JM, Gonzalez FJ, Desvergne B, Wahli W. Peroxisome proliferator-activated receptor alpha mediates the adaptive response to fasting. J Clin Invest. 1999; 103:1489-98.
26. Kersten S, Mansard S, Escher P, Gonzales FJ, Tafuri S, Desvergne $\mathrm{B}$ et al. The peroxisome proliferator-activated receptor $\alpha$ regulates amino acid metabolism. FASEB J. 2001; 15:1971-8.

27. Fujiwara Y, Yokoyama M, Sawada R, Seyama Y, Ishii M, Tsutsumi $\mathrm{S}$ et al. Analysis of comprehensive effects of polyunsaturated fatty acid on mRNA expression using a gene chip. J Nutr Sci Vitaminol. 2003; 49:125-32.

28. Vercauteren K, Pasko RA, Gleyzer N, Marino VM, Scarpulla RC. PGC-1-related coactivator: immediate early expression and characterization of a CREB/NRF-1 binding domain associated with cytochrome c promoter occupancy and respiratory growth. Mol Cell Biol. 2006; 26:7409-19.

29. Semple RK, Chatterjee VK, O'Rahilly S. PPAR gamma and human metabolic disease. J Clin Invest. 2006; 116:581-9.

30. Edvardsson U, Ljungberg A, Lindén D, William-Olsson L, PeilotSjögren H, Ahnmark A et al. PPAR $\alpha$ activation increases triglyceride mass and adipose differentiation-related protein in hepatocytes. J Lipid Res. 2006; 47:329-40.

31. Liang H, Ward WF. PGC-1alpha: a key regulator of energy metabolism. Adv Physiol Educ. 2006; 30:145-51.

32. Zhang Y, Castellani LW, Sinal CJ, Gonzalez FJ, Edwards PA. Peroxisome proliferator-activated receptor-gamma coactivator 1alpha (PGC-1alpha) regulates triglyceride metabolism by activation of the nuclear receptor FXR. Genes Dev. 2004; 18:157-69. 